\title{
Implementation of Mega-Projects for the Development of Problematic Territories of Siberia and Ural of Russia
}

\author{
Inna V. Mitrofanova \\ Institute of Social, Economic and Humanitarian Researches, of the Southern Scientific \\ Center of the Russian Academy of Sciences; Volgograd State University, Russia \\ Email:mitrofanova@volsu.ru \\ Aleksandr N. Zhukov \\ Volgograd Institute for Business, Russia \\ Email: labser@volsu.ru \\ Victoria V. Batmanova \\ Volgograd State University, Russia \\ Email: vbatmanova@mail.ru \\ Inna A. Mitrofanova \\ Volgograd State Technical University, Russia \\ Email:mia05011986@yandex.ru
}

Doi:10.5901/mjss.2015.v6n3s1p586

\section{Abstract}

Phenomenon of use of megaprojects as an instrument of territorial development has been poorly studied by the domestic (Russian) economic science that results in deficit of research directed on the integrated comparative analysis of processes of formation and realization of territorial megaprojects. Authors of the article set the task partly to fill this gap. Using the example of the historic infrastructural megaprojects (construction of Trans-Siberian Railroad (Transsib) and Baikal-Amur Mainline (BAM)). The authors examined the reasons for their successfulness and failures. The plans of the Russian Federal Government concerning the modernization these infrastructural megaprojects are revealed. Russia started another strategically crucial for the region of Ural and Russia in general megaproject "Ural Industrial - Ural Polar". The authors carried out an analysis of the stages of the life cycle of this contemporary important project and proved that it turned into a number of separate local investment projects which are not connected by a common conception. This circumstance lead to a considerable weakening of the cumulative integration results after its realization.

Keywords: territorial development; territorial megaprojects; strategic management; Baikal-Amur Mainline (BAM); Trans-Siberian Railroad (Transsib); Ural Industrial - Ural Polar.

\section{Introduction}

Megaprojects are generally thought to be large scale investment projects (more than 1 billion dollars of costs) with global character (independently of the spatial level of the realization). Megaproject can become an independent format of the development of the strategy of a particular territory or a district. Thus a territorial megaproject can be considered as a complex target program involving several regions. It can have a frontal, pendulum or nidal character in contrast to monoindustrial, local or conglomerate megaprojects. They usually present a complex of interrelated subsubjects from different industries that have a common idea or a general target (changes in the territorial economic space), available resources and a jpint organizational mechanism (development institute) (Flyvbierg, Skamris, Buhl, 2004, 2005). Subordinate programs of the territorial megaproject are usually carried out consequently or simultaneously within the same life cycle of the project and are aimed at the achievement of a more serious synergy effect compared with the projects that are realized autonomously (Altshuler, Luberoff, 2003; Gunton, 2003; Priemus, Flyvbierg, 2007).

In contrast to financial investments, territorial megaprojects are targeted on a concrete embodied result ensuring a 
long term effect on the transformation of the economic space.

Active realization of territorial megaprojects is a sequence of organizational, institutional and informational changes in the economic space of the global economic system. The processes of the design and the realization of territorial megaprojects initially imply: large scale preplan research, competence of developers and executives, efficient work of new organs of government and the activity of conventual development institutes, integration of state and private interests, publicity, candour, transparency, active use of crowdsourcing technologies, significant social and integrated results (Lehrer, Laidley, 2008; Priemus, Flyvbierg, 2007).

Real economic processes usually take place either around state agglomerations, large transport lines or huge geographic objects, rivers, for example. Such types of the development of territories exist in the whole world.

The article aims to meet a lack in research of the experience of the realization of territorial megaprojects in Russia; to reveal their importance as an instrument of regional development and in particular in the example of historic infrastructural megaprojects (construction of the Transsiberian Railway and the Baikal-Amur Mainline, realization of a contemporary megaproject "Ural Industrial - Ural Polar") to display peculiarities of the mechanism of their realization which contribute to the successfulness of the project; to give an assessment to the attained results; to reveal reasons for rebranding and to show the prospects of modernization.

\section{Literature Review}

Considerable contribution to the development of theory and practice in megaprojecting as an instrument of infrastructural development of territories was made by the following scientists: Altshuler A., Buhl Soren L., Flyvbierg B., Gunton T., Laidley J., Lehrer U., Luberoff D., Skamris Mette K., Priemus H. and others. They studied thoroughly in their papers risks, exposed antinomies, offered ways of social participation and responsibility distribution, gave an expert assessment of the consequence of the realization of well known in international practice local infrastructural megaprojects: English Channel tunnel, Öresund Bridge between Denmark and Sweden, Vasco da Gama Bridge in Portugal and others for regional economic development.

The research of the specificity of life cycle of large multisectoral projects directed on the integrated development of problematic territories of Russia was realized in few in number papers of soviet scientists: Aganbegyan A.I., Milner B.Z., Shniper R.I.

Analysis of historic and contemporary foreign experience of the realization of a number of integrated territorial megaprojects is presented in papers of the following contemporary Russian scientists: Kin A.A., Kibalov E.V., Mitrofanova I.V., Zhukov A.N., Yakunin V.I. and others.

\section{Research Methodology}

The methodological base of the study and attainment of scientific goals became the realization of the dialectical principles of research within a systematic approach. Authors used general scientific and specific methods of research: subjective and objective method, structural and functional, historical and logical, comparative, imitational, statistical and other types of analysis.

The reason for use of these methods is the necessity of integrated, systematic and critical study of the process of formation, realization of integrated, multisectoral (in contrast to local ones) megaprojects directed on the provision of a stable, balanced and competitive development of social and economic complex of a particular territory that will allow displaying problematic aspects of megaproject use as an instrument of regional development and, as a result, allow working out mechanisms of their correction or adjustment.

\section{Results Analysis}

\subsection{Plans of the modernization of the epoch meaningful infrastructural megaprojects in Russia}

Russia managed to realize some large scale territorial megaprojects in early XX century during the tsarist Russia and then in the second part of the XX century in the Soviet historic period. Two of them can be considered as the most interesting and notable projects. They are the construction of the Trans-Siberian Railway (Transsib) and the expansion of the economic space of the Baikal-Amur Mainline (BAM). The realization of the mentioned above constructions were a little different in the basic conception. Both of them kept the stability in diverse economic situations in the country during different historic periods in Russia. The state supported both cases the projects, supplied funds and reimbursed losses if 
there were any.

The decision to construct the Trans-Siberian Railway across the territory of the country was connected with the geostrategic and economic interests of the tsarist Russia. The country possesses vast territories, rich in mineral resources in the Western, Eastern Siberia and the Far East that without bias needed the economic mastery and development. The government also needed a means for the solution of military and political strategic goals and logically initiated the Trans-Siberian Railway project. The project targets varied flexibly according to the changing economic situation, for instance, when the transit traffic through Trans Siberian Railway turned out to be lower than expected excluding the period of the Russian-Japanese war, the emphasis was put on the economic development of the whole "territory adjoining the Trans-Siberian Railway". This maneuver lead to a considerable economic growth of the Siberian region. Two reconstructions took place in 1989 and 1903 in order to correct some defects that resulted in insufficient capacity of the main. By 1908 the project of Transsib became profitable (Aganbegyan, Shniper, 1980).

The construction of the Baikal-Amur Mainline was the first stage of a large scale program of the economic development of the Eastern Siberia and the Far East. This target program aimed at the creation of a new industrial region of Russia adjoining the Baikal-Amur Mainline. In 1970 the economic mastering of the Baikal-Amur Mainline territories was positioned by the government as a crucial task of the spatial development of the country. It was supposed to be connected with a new industrial belt in the Near North having relations with the transport line along the Trans-Siberian Railway. Nevertheless a lot of economists believe that the Baikal-Amur Mainline project proved to be unsuccessful. But this seems to be unfair because there were four large scale projects of the economic development of Siberia which included Ural and Kuznetsky, Angaro and Yenissey projects, a program of the forming of the oil and gas complex of the Western Siberia. The program of the economic development of the Baikal-Amur Mainline territory was one of them. But in the result of all projects in the whole are seen as positive ones. (Kibalov, Kin, 2007).

The necessity of the construction of the Baikal Amur Mainline became obvious already in post war period (19531974). Only in 1974 after the inclusion of the project of the Baikal-Amur Mainline into the XX year plan of the economic development of the former USSR the works began. The megaproject was revised, its design was specified and its elaboration started. The necessity of the construction was connected with the activation of the Soviet-Chinese relations in the economic and military spheres in the second half of 1960s. The Baikal-Amur Mainline was supposed to be used as a lateral military road as well as a railroad to transport the extracted mineral resources to the consumers in different parts of Europe and Asia. This segment of the railroad also had a transit and strategic character as was thought to be used as the oil transporting way into the countries of the Asian and Pacific region.

The mechanism of the construction of the Baikal-Amur Mainline had some drawbacks mentioned by the researchers. Nevertheless the realization of this project managed to mobilize resources, created a kind of hierarchy where the head of it had the right not only to dispose of the governmental resources within the established limits but also the opportunity to attract the necessary additional resources into the project even from the first person of the state leaving apart a bureaucratic distribution system (similar to the Trans-Siberian Railway megaproject) (Zhukov, 2012; Mitrofanova, 2011; Mitrofanova, Batmanova, Zhukov, 2012).

The reasons for the success of the realization of the epochal infrastructural projects in Russia can be found in the history of the country i.e.: highly qualified specialists, profound scientific research, large scale pre project research and forecasts seen as an independent stage; combination of the plan and market principles; efficient work of the institute of development that is considered as a type of the state and private partnership; high transparency, participation of general public, control of all the stages of the life cycle of the project from the part of the "main stakeholder", a single authority who could make all necessary corrections quickly without existing bureaucratic barriers (Zhukov, 2014; Zhukov, Mitrofanova, 2014; Yakunin, 2005).

In summer 2013 the Government of the Russian Federation declared that the Trans-Siberian Railway and BaikalAmur Mainline reached the limit of their carrying capacities as recently the eastern direction of the Russian Railroad started to attract huge cargo traffic. In July 2014 the modernization of Trans-Siberian Railroad and the construction of a new railroad of Baikal-Amur Mainline were officially started. The Russian Railroads Company has already begun constructing Baikal-Amur Mainline-2 (the expansion of the mains). The beginning of construction was dated to the 40 year anniversary of the start for the construction of Baikal-Amur Mainline that started in 1974.

Taking into consideration the decision of the government concerning the allocation of funds for the modernization of railroads of Russia the "Program of first priority measures concerning the infrastructure of Trans-Siberian Railway and Baikal-Amur Mainline" was developed.

Within the East Siberian railroad till 2017 the putting into operation of 30 segments of railroad with double ways instead of one way railroad of Baikal-Amur Mainline as well as the construction of 11 sidings and 5 halts is planned.

The Government of the Russian Federation agreed the scheme of financing of Baikal-Amur Mainline and Trans- 
Siberian Railway modernization till 2018 among the allocated 562 billion rubles (8,5 billion US dollars): 362 billion rubles (5,5 billion US dollars) are supposed to be spent on the Baikal-Amur Mainline, 200 billion rubles (3,1 billion US dollars) will be spent on the Trans-Siberian Railway. The distribution of the allocated funds is the following: 110 billion rubles (1,7 billion US dollars) will be allocated from the federal budget, 150 billion rubles (2,7 billion US dollars) will be allocated from the Fund of the National Wealth, 300 billion rubles (4,5 billion US dollars) will be given by the Russian Railroads Company. At the same time 16 billion rubles (242 million US dollars) will be needed only for the development of the West Siberian railroad main (expansion of the Kuzbass-Mezhdurechensk and Kuzbass-Mariinsk sectors). The total volume of financing of railroad mains development is assessed as 1,2 trillion rubles (18,2 billion US dollars) taking into consideration 560 billion rubles (8,5 billion US dollars) the allocation of which obtained the approval of the Government and the Russian Railroads Company) ${ }^{1}$. Modernization in authors' opinion will allow increasing the carrying capacity of BAM and Transsib by 2020 till 75 million tons per year.

The realization of large scale infrastructural projects of Baikal-Amur Mainline and Trans-Siberian Railway is expected to contribute to a sustainable development of the Russian Far East and Zabaikalsky territory of Russia, to the solution of crucial tasks set by federal and regional authorities concerning the use of mineral resources, industrial and transit expansion in the East of the country. But the problem of a precise assessment of the reserves of natural resources in the mentioned region remains important. Without this the creation of the capillary railroad infrastructure, adjoining the Baikal-Amur Mainline seems to be complicated. The modernization of the Baikal-Amur Mainline is supposed to result in the creation of a new territorial and industrial complex, specializing in extraction and reprocessing of natural resources and energy development.

\subsection{Reasons for rebranding of the Russian megaproject "Ural Industrial - Ural Polar".}

The Investment Fund of the Russian Federation today allocates funds for 15 contemporary megaprojects realized by the Federal government. The money that is given for these projects from this fund is hardly sufficient for obtaining a systematic effect for the economy that's why another sources are planned to be attracted. Structured territorial megaprojects that are planned for realization via the state and private partnership are approved by federal authorities and account for more than 150 billion US dollars. The mentioned above large scale projects imply the development of new territories where the social and economic level is below Russian average indices (Mitrofanova, Mitrofanova, 2013).

Megaprojects "Ural Industrial - Ural Polar", "Belkomur", "Integrated Development of the Lower Part of Angara", "Integrated Development of the Southern Yakutia" and others according to the idea of the developers are directed on the creation of a new economic skeleton in the problematic Russian regions and districts, formation of the premises for an economically dynamic development of Siberia and the Russian Far East.

The "Strategy of social and economic development of the Ural federal district for the period till 2020" declared the megaproject "Ural Industrial - Ural Polar" was declared as the main constituent. The mentioned above program (Ural Industrial - Ural Polar) is supposed to contribute to the creation of important sectors of the economy (transport, energy, natural and resource industries) by means of a number of measures.

The railroad main along the eastern slope of the Ural mountains (Polunochnoye - Obskaya) is thought to become the nucleus of the transport infrastructure of the region. This rail road is meant to connect on the shortest track the territory of the developed industrial Ural with the zone rich in mineral reserves of the Polar Ural, the zone of the oil extraction, by means of giving the outlet to the Northern Sea Route, to Norilsk.

The development of deposits of natural resources in the Polar and Nearpolar Ural is thought to replace completely the chromic ores that are delivered to Russia from other countries by the manganese, iron and phosphorites from that region. The project is supposed to result in the creation of more than 50 new enterprises, 66 thousand jobs in the mining industry, transport, 3 thousand jobs in the timber industry, 3500 jobs in the oil and gas industry (Zhukov, Mitrofanova, 2013).

The realization of the megaproject "Ural Industrial - Ural Polar" was supposed to create in the Arctic and in the Polar Ural a large territorial and industrial complex. The mentioned above megaproject is considered as an innovative project of the regional level, capable of introducing the newest technical and technological achievements into the transport, oil and gas and energy industry. Due to this fact in 2006-2010 the megaproject "Ural Industrial-Ural Polar" was included into the strategic documents of the country i.e. a long term program of the subsoil research and the reproduction of the raw material base, general scheme of the location of the energy power plants, strategy of the rail road transport

1BAM i Transsib - raskhody na modernizatsiyu [BAM and Transsib: expenses for modernization] [Online]. Available: //www.transportmm. ru/novosti-logistiki/2110-bam-i-transsib-rasxody-na-modernizacziyu.html (July 13, 2014). 
development, long term conception of the social and economic development of the Russian Federation.

The managing company of the Ural megaproject that existed in 2006-2011 was created in the form of the state and private partnership. The regions from the Ural Federal district were included into the number of shareholders. The corporation "Ural Industrial-Ural Polar" was established in 2006 but the construction process started only in 2011. During the period 2006-2009 the company dealt only with the design of project documentation. More than ten subsidiary firms were established and they regularly generated losses. In 2010 local projects that were realized within the general conception were grouped into separate parts for a better management: transport, mining and energy. In February 2012 the decision about the transformation of the Public Company "Corporation Ural Industrial - Ural Polar" into the Public Company "Corporation of Development" was taken.

The parts of the megaproject that dealt with transportation and mining initially were closely related. The basic calculation of the Ural megaproject was made by the Geology and Oil Institute of Scientific Research of the Western Siberia. 8 billion rubles (about 160 million US dollars) were spent on the development of deposits of natural reserves that were not found and turned out to be "fairy tales". The idea to connect the mining territories with industrial enterprises, new settlements for workers and power objects by railroad branches remained on paper. The situation resulted in another costly geological extraction works in order to assess the reserves of the mining raw materials. The earlier forecasts proved to be inexact and considerably exaggerated.

In 2010 the calculation showed that there would be only 5 million tons of the mineral resources to be transported by the railroad instead of 25 tons necessary for a full load of the railroad main. That's why the decision was taken to abandon the construction of the principal railroad main within the Ural megaproject: a railroad along the Eastern slopes of Ural mountains between the stations Polunochnaya and Obskaya. Today the corporation of the development focused its efforts on the construction of the road Obskaya-Korochaevo (Northern latitudinal route). This is a part of an unfinished railroad of the Soviet period - Transarctic main. The federal budget will not allocate fund for this railroad (North latitudinal route). Even today this segment of the rail road allows transporting up to 3-4 million tons of loads but after the end of construction the volume is expected to be 30 million tons (Zhukov, 2012; Zhukov, 2014).

The public company "Corporation Ural Industrial - Ural Polar" had to be rebranded on the one hand due to the expansion of its activity and on the other hand due to a certain deviation from the conception of the megaproject "Ural Industrial - Ural Polar". "Corporation of Development" was created instead of the mentioned above company. The new firm became a servicing company of the oil and gas industry of the Western Siberia and an engineering company dealing with the construction of the infrastructural objects - transport, energy and social ones (housing, kindergartens, car roads etc). (Mitrofanova, Zhukov, 2014).

The investment megaproject in the Urals dealt with the development of deposits of natural resources in the Polar zone of the Urals. During six years of its implementation it turned into a number of local investment projects of different types (optical fiber communications, reprocessing of chicken eggs). This strategically important Ural megaproject transformed into a several local investments without a common idea or conception and this circumstance made the integrated effect from its realization less important.

In 2006 the megaproject "Ural Industrial - Ural Polar" at the meeting of the party "United Russia" was said to be one of the important projects that the party will take care of. But in 2011 this project was excluded by the Russian Federation form the list of priority investment projects.

\section{Conclusion}

Thus, the research by the modern economic science of the phenomenon of the creation and implementation of territorial megaprojects has not acquired an integrated character. Meanwhile the historic and contemporary Russian experience prove that these are territorial megaprojects that are capable of generating the development of conjoint sectors of the economy of a high processing, with a developed sector of services and R\&D that can become a nucleus of modern clusters, center of the interregional economic development, points of bifurcation of the territorial development. Territorial megaprojects in contrast to monoindustrial, conglomerate large investment projects (including a number of local and autonomous projects) or to purely financial investments have a large scale proactive potential, catalyzing both synergetic and multiplicative effects, oriented on an embodied material result capable of having a long term impact on the transformation of the architectonic of the economic space not only for the region where the project is being realized but also in regions bordering on them.

Specific character of large scale projects of the territorial development that are being realized today has been poorly studied so far and shows the deficit of the research directed on the integrated comparative analysis of the processes of the formation and realization of specific risks, typical of different types of their life cycles as well as on the 
assessment of social, integrated effects of megaprojects, analysis of the prospects of the postproject use of the constructed objects.

\section{References}

Aganbegyan, A.G., Shniper, R.I. (1980). Regionalnye komlexnye programmy (na primere Sibiri) [Regional integrated programs (on the example of Siberia)] // In: Programmnoye tselevoye upravleniye sotsialisticheskim proizvodstvom: voprosy teorii i praktiki [Programmed and target management by social industry: problems of theory and practice] / Edited by A.G. Aganbegyan, V.Z. Milner, G.H. Popov. Moscow: Edition "Ekonomika", 1980, 83-110.

Altshuler, A., Luberoff, D. (2003). Mega-Projects: The Changing Politics of Urban Public Investment. Washington, DC: Brookings Institution.

Flyvbierg, B., Skamris Mette, K., Buhl Soren, L. (2004). What Causes Cost Overrun in Transport Infrastructure Projects. Transport Reviews, Vol. 24, number 1, 3-18.

BAM i Transsib - raskhody na modernizatsiyu [BAM and Transsib: expenses for modernization] [Online]. Available: I/www.transportmm.ru/novosti-logistiki/2110-bam-i-transsib-rasxody-na-modernizacziyu.html (July 13, 2014).

BAM i Transsib: vchera, segodnia, zavtra. V epitsentre [BAM and Transsib: yesterday, today and tomorrow. In the epicenter] [Online]. Available //altairk.ru/new/economy/the_baikal-amur_and_trans siberian_railway_yesterday_today_tomorrow. (July 13, 2014).

Flyvbierg, B., Skamris Mette, K., Buhl Soren, L. (2005) How (In)accurate are Demand Forecasts in Public Works Projects. The Case of Transportation. Journal of the Planning Association. Vol. 71, 2, 131-146.

Gunton, T. Megaprojects and Regional Development: Pathologies in Project Planning. (2003). Regional Studies: The Journal of the Regional Studies Association. Volume 37, 5, 505-519.

Kibalov, E.B., Kin, A.A. (2007). Problema ucheta faktora neopredelennosti pri otsenke ozhidaemoy effektivnosti krupnomashtabnykh investitsionnykh projektov [Problems of uncertainty factor at the assessment of the expected efficiency of large scale investment projects]. Region: ekonomika i sotsiologia [Region: economy and sociology], 3, 67-91.

Lehrer, U., Laidley, J. (2008). Old Mega-projects Newly Packaged? Waterfront Redevelopment in Toronto. International Journal for Urban and Regional Research, 32 (4), 786-803.

Mitrofanova, I. (2011). Elaboration of the macroregion development strategy in the territorial megaproject format: prospects for Russia. Journal of International Scientific Publications: Economy \& Business. Vol. 5, part 2, 50-57.

Mitrofanova, I., Batmanova, V., Zhukov, A. (2012). Analysis of the experience of the realization and the assessment of the contemporary prospects of the modernization and territorial megaprojects in Russia. Journal of International Scientific Publications: Economy \& Business. Vol. 6, part 2, 142-152.

Mitrofanova, I.V., Mitrofanova, I.A. (2013). Megaprojects as constructors of the mesoeconomic spaces of the contemporary Russia: potential, risks, trends and prospects. Journal of International Scientific Publications: Economy \& Business. Vol. 7, part 2, $167-177$

Mitrofanova, I.V., Zhukov, A.N. (2014). Infrastrukturniye megaproyekty Transsib i BAM: vtoroye rozhdenie [Infrastructural megaprojects of Transsib and BAM: second birth]. Vestnik Yuzhnogo nauchnogo tsentra [Bulletin of the Southern Scientific center], 10, 1, 7989.

Priemus, H., Flyvbierg, B. (2007). Decision-making on mega-projects: cost-benefit analysis, planning and innovation, Edward Elgar Publishing.

Yakunin, V.I. (2005). Formirovaniye geostrtegiy Rossii: transportnaya sostavliayushchaya [Creation of geostrategies of Russia: transport compontent], Moscow.

Zhukov A.N. (2012). Istorichesky opyt territorialnogo megaproektirovaniya v Rossii [Historic experience of the territorial megaprojecting in Russia]. Regionalnaya ekonomika. Yug Rossii [Regional economy. South of Russia], 13, 218-230.

Zhukov, A.N. (2014) Riski realizatsii territorialnykh megaproektov [Risks of the realization of territorial megaprojects]. Regionalnaya ekonomika. Yug Rossii [Regional economy. South of Russia], 1, 33-431.

Zhukov, A.N., Mitrofanova, I.V. (2013). Rebrending i riski megaproyekta "Ural Promyshlenny - Ural Polyarny" [Rebranding and risks of the megaproject "Ural Industrial - Ural Polar"]. Regionalnaya ekonomika: teoria i praktika [Regional economics: theory and practice], 11, 2-13. 